\title{
PENGGUNAAN DATA AIS-IRSMS UNTUK PREDIKSI KECELAKAAN MELIBATKAN SEPEDA MOTOR PADA RUAS JALAN DI KOTA SURABAYA
}

\author{
Use of AIS-IRSMS Data for Motorcycles Involving Accidents Predictions on Roads \\ in Surabaya City
}

\author{
Muhammad Zainul Arifin \\ Jurusan Teknik Sipil \\ Universitas Brawijaya \\ Jl. MT. Haryono No.167 \\ Malang, Jawa Timur \\ mzaub@ub.ac.id
}

\author{
Imma Widyawati Agustin \\ Jurusan Perenc. Wilayah dan Kota \\ Universitas Brawijaya \\ Jl. MT. Haryono No.167 \\ Malang, Jawa Timur \\ imma_umm@yahoo.com
}

\author{
Sonya Sulistyono \\ Jurusan Teknik Sipil \\ Universitas Jember \\ Jl. Kalimantan 37 \\ Jember, Jawa Timur \\ sonya.sulistyono@unej.ac.id
}

\begin{abstract}
Accidents involving motorcycles in Surabaya tend to increase. Recorded from 2014 to 2016 were reached 721, 929, and 1,325 accidents. This phenomenon is certainly not beneficial for the community and road transport policymakers. This study was conducted to determine the characteristics of motorcycle riders and accidents involving motorcycles. This research further develops the estimation of accident prediction involving a motorcycle in Surabaya City. Accident data compiled from AIS-IRSMS to know the characteristics of users and accidents using the accident approach. The research location was conducted in accident-prone areas from January 2014 to February 2017, also using AIS-IRSMS. With the Generalized Linear Models (GLMs), the result of the estimation of accident estimation involving a motorcycle that is $\mathrm{McA}=0,00225 \mathrm{Q}^{1,030} \mathrm{e}^{(0,034 \mathrm{~S})}$. Accidents involving motorcycles are heavily influenced by the number of vehicles on the road and the speed of the vehicle.
\end{abstract}

Keywords: accident, motor cycle, AIS-IRSMS, accident frequency, GLMs

\begin{abstract}
Abstrak
Kecelakaan melibatkan sepeda motor di Kota Surabaya cenderung mengalami peningkatan. Tercatat tahun 2014 hingga 2016 mencapai 721, 929 dan 1.325 kejadian kecelakaan. Fenomena ini tentunya tidak menguntungkan bagi masyarakat dan pengambil kebijakan terkait transportasi jalan raya. Penelitian ini dilakukan untuk mengetahui karakteristik pengendara sepeda motor terlibat kecelakaan dan kecelakaan melibatkan sepeda motor. Lebih lanjut penelitian ini melakukan pengembangan estimasi prediksi kecelakaan melibatkan sepeda motor di Kota Surabaya. Data kecelakaan dikompulir dari AIS-IRSMS untuk mengetahui karakteristik penguna dan kecelakaan menggunakan pendekatan frekwensi kejadian. Lokasi penelitian dilakukan pada daerah rawan kecelakaan sepanjang Januari 2014 hingga Februari 2017 juga menggunakan bantuan AIS-IRSMS. Menggunakan metode Generalized Linear Models (GLMs), hasil penelitian diperoleh estimasi prediksi kecelakaan melibatkan sepeda motor yaitu $\mathrm{McA}=0,00225 \mathrm{Q}^{1,030} \mathrm{e}^{(0,034 \mathrm{~S})}$. Kecelakaan melibatkan sepeda motor sangat dipengaruhi oleh banyaknya kendaraan di jalan dan kecepatan kendaraan.
\end{abstract}

Kata Kunci: kecelakaan, sepeda motor, AIS-IRSMS, frekuensi kejadian, GLMs

\section{PENDAHULUAN}

Sepeda motor sebagai sarana transportasi telah menjadi pilihan utama masyarakat, meskipun memiliki kerentanan kecelakaan yang tinggi. Fakta menunjukkan kepemilikan sepeda motor tahun 2015 mencapai 98,881 juta atau 81,45\% dari kepemilikan kendaraan bermotor di Indonesia, dan dengan pertumbuhan terakhir 6,35\% (Badan Pusat Statistik, 2017). Tentunya hal ini akan berpengaruh terhadap dominasi sepeda motor pada lalu lintas 
di jalan raya. Sementara itu kepemilikan kendaraan bermotor di Kota Surabaya dengan jumlah penduduk 2.943.528 jiwa pada tahun 2015 mencapai 2.126.168 kendaraan. Kepemilikan sepeda motornya mencapai $77,88 \%$ atau sebanyak 1.655 .891 kendaraan dengan pertumbuhan terakhir 5,70\% (Badan Pusat Statistik Kota Surabaya, 2016). Peningkatan penggunaan sepeda motor sebagai moda transportasi, turut pula meningkatkan potensi jumlah kecelakaan yang melibatkan sepeda motor. Keterlibatan sepeda motor dalam kecelakaan mencapai 67,9\%, menunjukkan bahwa sepeda motor merupakan jenis kendaraan yang paling rentan terhadap kecelakaan (Suraji dan Sulistio, 2010). Keterlibatan sepeda motor dalam kecelakaan lalu lintas di Kota Surabaya tahun 2014 hingga 2016 berturut-turut sebanyak 721, 929 dan 1.325 kejadian (data AIS-IRSMS diakses melalui Ditlantas Polda Jawa Timur). Kecelakaan melibatkan sepeda motor menjadi salah satu permasalahan lalu lintas Kota Surabaya. Kecelakaan dipengaruhi oleh interaksi faktor lingkungan, kendaraan dan pengemudi, dimana faktor pengemudi berkontribusi lebih dari 90 persen dalam mempengaruhi kecelakaan (Dinas Perhubungan Kota Surabaya, 2016a).

Penelitian kecelakaan lalu lintas melibatkan sepeda motor perlu terus dikembangkan, melihat fenomena keterlibatan sepeda motor dalam kecelakaan lalu lintas terus meningkat. Prediksi jumlah kecelakaan melibatkan sepeda motor menarik untuk dikaji untuk meninjau faktor-faktor krusial yang dapat mempengaruhi terjadinya kecelakaan melibatkan sepeda motor. Penelitian prediksi kecelakaan lalu lintas terus berkembang khsusnya kecelakaan di ruas jalan. Xie dan Zhang (2007) meneliti pada ruas jalan di Toronto Canada, dan Ackaah dan Salifu (2011) meneliti untuk ruas jalan di Ghana. Sementara Suraji dan Sulistio (2010) meneliti kecelakaan sepeda motor pada suatu ruas jalan, Abusini et al. (2010) meneliti pada beberapa ruas jalan di Kota Batu, Machsus et al. (2013). melakukan penelitian pada jalan arteri Kota Surabaya, dan Bolla et al. (2014) melakukan penelitian pada ruas jalan di Kota Atambua. Metode pendekatan yang digunakan mulai regresi linier, model Bayesian neural network, generalized linear models maupun generalized additive models.

Penelitian ini dilakukan untuk lebih mengembangkan dari penelitian sebelumnya khususnya penelitian yang pernah dilakukan di Kota Surabaya. Obyek penelitian diperluas tidak hanya pada jalan arteri saja. Metode pendekatan untuk melakukan prediksi kecelakaan melibatkan sepeda motor mengunakan teknik Generalized Linear Models (GLMS) dengan basis data kecelakaan menggunakan database yang terekam dalam AISIRSMS (Accident Information System-Integrated Road Safety Management System) Korlantas Polri melalui Ditlantas Polda Jawa Timur. Sedangkan untuk meninjau karakteristik kecelakaan yang terjadi menggunakan analisis deskriptif frekuensi.

\section{PENGGUNAAN AIS-IRSMS UNTUK PENGUMPULAN DATA DAN IDENTIFIKASI AWAL}

Sistem Manajemen Keselamatan Jalan Terpadu (IRSMS) mengembangkan database kecelakaan dan analisis terpadu sistem lalu lintas jalan. Merupakan Proyek Strategis Infrastruktur Jalan (SRIP) yang dilaksanakan Direktorat Jenderal Bina Marga, Departemen Pekerjaan Umum sejak akhir 2007. Lebih lanjut untuk mendukung hal tersebut dikembangkan Sistem Informasi Kecelakaan (AIS) oleh Korlantas Polri. Informasi terkait setiap kejadian kecelakaan merupakan dasar bagi semua pihak yang memiliki intervensi meningkatkan keselamatan di jalan. AIS-IRSMS menyediakan data kecelakaan ter-update, handal dan dapat diverifikasi. (http://korlantas-irsms.info/irsms_ais) 
Sistem database yang tersedia dalam AIS-IRSMS sangat memungkinkan menyediakan data historis maupun pengklasifikasian data tertentu pada periode tertentu. Penelitian ini mengoptimalkan pemanfaatan database dalam AIS-IRSMS untuk melakukan analisa karakteristik dan prediksi kecelakaan melibatkan sepeda motor. Penggunaan AIS-IRSMS bersama tim Ditlantas Polda Jawa Timur dalam penelitian ini digunakan untuk:

1. Melakukan identifikasi lokasi rawan kecelakaan pada ruas jalan di Kota Surabaya kurun waktu 3 tahun terakhir yaitu tahun 2014 hingga Februari 2017.

2. Melakukan pengklasifikasian karakteristik pengendara sepeda motor terlibat kecelakaan dan karakteristik kecelakaan melibatkan sepeda motor.

3. Melakukan filter dan inventarisasi data kecelakaan melibatkan sepeda motor pada lokasi rawan kecelakaan, sebagai obyek lokasi penelitian.

Hasil identifikasi lokasi rawan kecelakaan diperoleh sebanyak 24 ruas jalan di Kota Surabaya. Selanjutnya 24 ruas jalan tersebut merupakan obyek penelitian untuk dilakukan analisis estimasi prediksi kecelakaan yang melibatkan sepeda motor.

\section{KARAKTERISTIK KECELAKAAN}

Karakteristik kecelakaan yang dimaksud dalam penelitian ini meliputi karakteristik pengendara sepeda motor dan karakteristik kecelakaan melibatkan sepeda motor. Dalam Khisty (1990) disebutkan karakteristik pengendara berkaitan dengan karakteristik sosial ekonomi, karakteristik pergerakan, perilaku dan sikap manusia yang nantinya akan sedikit banyak mempegaruhi penyusunan estimasi prediksi kecelakaan melibatkan sepeda motor. Dalam penelitian ini akan meninjau karakteristik sosial ekonomi. Sedangkan karakteristik kecelakaan yang ditinjau meliputi waktu kejadian, kondisi cuaca saat kejadian, geometri lokasi kejadian, jenis kecelakaan, jenis/tingkat cedera, dan tingkat kerugian.

Menggunakan AIS-IRSMS, data diinventarisasi untuk jenis kecelakaan yang melibatkan sepeda motor sepanjang tahun 2014 hingga Februari 2017 di Kota Surabaya. Sebanyak 3.895 kejadian kecelakan melibatkan sepeda motor tercatat. Data selanjutnya diklasifikasikan untuk meninjau karakteristik pengendara sepeda motor dan kecelakaan melibatkan sepeda motor. Tiga variabel pokok sosio-ekonomi pengguna sepeda motor terlibat kecelakaan ditinjau, yaitu jenis kelamin, usia dan profesi. Karakteristik pengendara sepeda motor terlibat kecelakaan didominasi pengendara berjenis kelamin laki-laki mencapai $64,2 \%$. Usia pengendara sepeda motor terlibat kecelakaan berusia antara $15-25$ tahun mencapai $28 \%$. Sementara untuk profesi pengendara didominasi pegawai swasta mencapai $68,4 \%$. Sementara terkait karakteristik kecelakaan menonjol memperlihatkan waktu kejadian kecelakaan terjadi antara pukul 12.00-17.59 WIB mencapai 33,6\%. Cuaca saat kejadian kecelakaan dalam kondisi cerah (90,9\%). Sementara 84,5\% kejadian kecelakaan terjadi pada geometrik jalan lurus. Untuk jenis kecelakaan 79,7\% merupakan kecelakaan ganda, dan 49,9\% kecelakaan dengan jenis cedera adalah luka ringan.

\section{KARAKTERISTIK JALAN DAN LALU LINTAS}

Tinjauan karakteristik jalan dan lalu lintas dalam penelitian ini dilakukan pada 24 ruas jalan yang memiliki historis data kecelakaan tinggi dan korban meninggal dunia tinggi dibandingkan ruas-ruas jalan yang lain. Untuk penentuan lokasi yang memiliki historis data kecelakaan dan korban meninggal dunia tinggi didianalisis menggunakan bantuan 
AIS-IRSMS. Karakteristik geometrik jalan dan lalu lintas pada lokasi penelitian ditunjukkan pada Tabel 1 berikut.

Tabel 1. Karakteristik geometrik dan lalu lintas ruas jalan lokasi penelitian

\begin{tabular}{|c|c|c|c|c|c|c|c|c|}
\hline \multirow{2}{*}{ Nama Jalan } & \multirow{2}{*}{$\begin{array}{l}\text { Fungsi } \\
\text { Jalan }\end{array}$} & \multirow{2}{*}{$\begin{array}{c}\text { Tipe } \\
\left.\text { Jalan }^{*}\right)\end{array}$} & \multicolumn{2}{|c|}{ Lebar Lajur (m) } & \multicolumn{2}{|c|}{ Lebar Bahu (m) } & \multirow{2}{*}{$\begin{array}{l}\text { Vol. Total } \\
\text { (smp/jam) }\end{array}$} & \multirow{2}{*}{$\begin{array}{c}\text { Kecepatan } \\
(\mathbf{k m} / \mathbf{j a m})\end{array}$} \\
\hline & & & Arah 1 & Arah 2 & Arah 1 & Arah 2 & & \\
\hline Ahmad Yani & AP & $6 / 2 \mathrm{D}$ & 9,35 & 9,35 & 1 & 1 & 9675,23 & 43,60 \\
\hline Arjuno & $\mathrm{AP}$ & $6 / 2 \mathrm{D}$ & 9,7 & 9,5 & - & - & 11118,92 & 32,58 \\
\hline Basuki Rahmat & $\mathrm{AP}$ & 4/1 UD & \multicolumn{2}{|c|}{13,8} & \multicolumn{2}{|c|}{-} & 5708,22 & 24,63 \\
\hline Darmo & AS & $6 / 2 \mathrm{D}$ & 11,5 & 11,5 & 1 & 1 & 5807,70 & 25,30 \\
\hline Demak & $\mathrm{AP}$ & $6 / 2 \mathrm{D}$ & 9,9 & 9,7 & - & - & 3472,45 & 25,26 \\
\hline Diponegoro & $\mathrm{AP}$ & $6 / 2 \mathrm{D}$ & 10,5 & 10,7 & 1 & 1 & 5713,65 & 25,41 \\
\hline Indrapura & AS & 4/1 UD & \multicolumn{2}{|c|}{20,1} & \multicolumn{2}{|c|}{2} & 4688,42 & 50,73 \\
\hline Ir. H. Soekarno & $\mathrm{KP}$ & $6 / 2 \mathrm{D}$ & 9,7 & 10 & - & - & 6440,10 & 55,88 \\
\hline Gubeng & $\mathrm{AP}$ & 4/1 UD & \multicolumn{2}{|c|}{13,9} & \multicolumn{2}{|c|}{-} & 5983,59 & 29,12 \\
\hline Gunung Sari & KP & $4 / 2 \mathrm{D}$ & 7,2 & 7,2 & 0,5 & 0,5 & 4624,10 & 20,79 \\
\hline $\begin{array}{l}\text { Jagir } \\
\text { Wonokromo }\end{array}$ & $\mathrm{AS}$ & $2 / 2 \mathrm{UD}$ & 4,8 & 4,8 & 0,5 & 0,5 & 2865,70 & 28,57 \\
\hline Jemursari & AS & $6 / 2 \mathrm{D}$ & 10 & 9,8 & 1 & 1 & 4084,20 & 35,36 \\
\hline Kedung Cowek & KP & $6 / 2 \mathrm{D}$ & 13,8 & 14,2 & - & - & 4032,99 & 27,50 \\
\hline Kenjeran & AS & $6 / 2 \mathrm{D}$ & 9,7 & 9,6 & 0,5 & 0,5 & 4370,80 & 21,41 \\
\hline Kertajaya & AS & $6 / 2 \mathrm{D}$ & 8 & 8 & - & - & 6162,36 & 23,70 \\
\hline $\begin{array}{l}\text { Kusuma } \\
\text { Bangsa }\end{array}$ & $\mathrm{AP}$ & $6 / 2 \mathrm{D}$ & 9 & 9,6 & - & - & 4869,10 & 29,12 \\
\hline Mastrip & KS & $2 / 2 \mathrm{UD}$ & 6,25 & 6,25 & 1,5 & 1,5 & 1845,83 & 48,42 \\
\hline $\begin{array}{l}\text { Mayjen } \\
\text { Sungkono }\end{array}$ & AS & $6 / 2 \mathrm{D}$ & 10,5 & 10,5 & - & - & 8631,14 & 19,55 \\
\hline Menganti & $\mathrm{KP}$ & $4 / 2 \mathrm{D}$ & 7,4 & 6,7 & - & - & 6207,35 & 21,44 \\
\hline Ngagel & $\mathrm{AP}$ & $2 / 2 \mathrm{UD}$ & 6 & 6 & 0,5 & 0,5 & 4921,70 & 34,07 \\
\hline $\begin{array}{l}\text { Ngagel Jaya } \\
\text { Selatan }\end{array}$ & AS & $4 / 2 \mathrm{D}$ & 8,5 & 9 & 1 & 1 & 6207,40 & 20,97 \\
\hline Sememi & $\mathrm{KS}$ & $2 / 2 \mathrm{UD}$ & 3,7 & 3,4 & - & - & 4047,45 & 51,54 \\
\hline $\begin{array}{l}\text { Tambak } \\
\text { Osowilangun }\end{array}$ & $\mathrm{KP}$ & $4 / 2 \mathrm{D}$ & 8,9 & 9,3 & - & - & 3621,88 & 39,70 \\
\hline Wonokromo & $\mathrm{AP}$ & $6 / 2 \mathrm{D}$ & 11,5 & 11,5 & - & - & 12594,03 & 21,83 \\
\hline
\end{tabular}

*) AP = Arteri Primer; AS = Arteri Sekunder; KP = Kolektor Primer; KS = Kolektor Sekunder

Sumber: Dinas Perhubungan Kota Surabaya (2016a dan 2016b) dan Hasil Survey (2017)

\section{PREDIKSI KECELAKAAN SEPEDA MOTOR}

\section{Estimasi Prediksi Kecelakaan Melibatkan Sepeda Motor}

Pengembangan prediksi kecelakaan sepeda motor telah dibahas dalam beberapa studi dalam Xie dan Zhang (2007), Suraji dan Sulistio (2010), Abusini et al. (2010), Ackaah dan Salifu (2011), Machsus et al. (2013), dan Bolla et al. (2014). Penelitian ini melakukan 
estimasi prediksi kecelakaan dengan mencari hubungan antara kecelakaan yang melibatkan sepeda motor dengan variabel penjelas yaitu karakteristik jalan dan karakteristik lalu lintas pada ruas jalan lokasi studi menggunakan metode GLMs.

McCullagh dan Nelder (1989) menyatakan bahwa teknik GLMs menggunakan struktur non normal error dan biasanya menggunakan metode poisson atau negatif binomial akan menghasilkan koefisien variabel yang tidak menyimpang dengan standar eror minimal. Penelitian ini melakukan estimasi prediksi menggunakan persamaan eksponensial, dengan persamaan umum sebagai berikut:

$$
M c A=k F L O W^{\beta 0} E X P^{(\beta 1 X 1+\beta 2 X 2+\beta 3 X 3+\cdots)}
$$

Dimana McA adalah jumlah kecelakaan yang melibatkan sepeda motor per-tahun, FLOW adalah arus lalu lintas dalam satuan smp/jam, $\mathrm{k}$ dan $\beta$ adalah parameter-parameter yang akan diestimasi, dan $\mathrm{x}$ adalah variabel penjelas. Tinjauan variabel penjelas karakteristik jalan meliputi lebar lajur, jumlah lajur, bahu, median dan jumlah arah. Sementara tinjauan untuk variabel penjelas karakteristik lalu lintas meliputi arus dan kecepatan.

Tabel 2. Hasil uji korelasi data

\begin{tabular}{|c|c|c|c|c|c|c|c|c|c|}
\hline & & $\mathrm{McA}$ & Kecepatan & Lebar_Lajur & Bahu & Jumlah_Lajur & Median & Jumlah_Arah & Ln_Arus \\
\hline \multirow[t]{3}{*}{ McA } & $\begin{array}{l}\text { Pearson } \\
\text { Correlation }\end{array}$ & 1 & ,299 & ,107 & ,349 & ,218 & ,264 & ,319 & ,353 \\
\hline & Sig. (2-tailed) & & ,201 & ,654 & ,132 & ,356 & ,261 &, 170 & ,127 \\
\hline & $\mathrm{N}$ & 20 & 20 & 20 & 20 & 20 & 20 & 20 & 20 \\
\hline \multirow[t]{3}{*}{ Kecepatan } & $\begin{array}{l}\text { Pearson } \\
\text { Correlation }\end{array}$ &, 599 & 1 &,- 206 &,- 014 &,- 305 &,- 393 &,- 116 &,- 263 \\
\hline & Sig. (2-tailed) & ,201 & & ,335 & 949 & ,147 & ,057 &, 591 & ,215 \\
\hline & $\mathrm{N}$ & 20 & 24 & 24 & 24 & 24 & 24 & 24 & 24 \\
\hline \multirow[t]{3}{*}{ Lebar_Lajur } & $\begin{array}{l}\text { Pearson } \\
\text { Correlation }\end{array}$ & ,107 &,- 206 & 1 &,- 004 & $825^{* *}$ &, $673^{* *}$ & ,128 & ,331 \\
\hline & Sig. (2-tailed) & ,654 & ,335 & & ,986 &, 000 &, 000 &, 552 & ,115 \\
\hline & $\mathrm{N}$ & 20 & 24 & 24 & 24 & 24 & 24 & 24 & 24 \\
\hline \multirow[t]{3}{*}{ Bahu } & $\begin{array}{l}\text { Pearson } \\
\text { Correlation }\end{array}$ & ,449 &,- 014 &,- 004 & 1 &,- 166 &,- 092 & ,126 &,- 116 \\
\hline & Sig. (2-tailed) & ,132 & ,949 & ,986 & & ,438 & ,670 &, 557 &, 589 \\
\hline & $\mathrm{N}$ & 20 & 24 & 24 & 24 & 24 & 24 & 24 & 24 \\
\hline \multirow[t]{3}{*}{ Jumlah_Lajur } & $\begin{array}{l}\text { Pearson } \\
\text { Correlation }\end{array}$ & ,218 &,- 305 &, $825^{* *}$ &,- 166 & 1 &, $806^{\star *}$ & ,188 &, $538^{* *}$ \\
\hline & Sig. (2-tailed) & ,356 & ,147 &, 000 & ,438 & &, 000 & ,379 &, 007 \\
\hline & $\mathrm{N}$ & 20 & 24 & 24 & 24 & 24 & 24 & 24 & 24 \\
\hline \multirow[t]{3}{*}{ Median } & $\begin{array}{l}\text { Pearson } \\
\text { Correlation }\end{array}$ & ,264 &,- 393 &, $673^{* *}$ &,- 092 &, $806^{* *}$ & 1 &, $589^{* \star}$ &, $417^{*}$ \\
\hline & Sig. (2-tailed) & ,261 &, 057 &, 000 &, 670 &, 000 & &, 002 &, 043 \\
\hline & $\mathrm{N}$ & 20 & 24 & 24 & 24 & 24 & 24 & 24 & 24 \\
\hline \multirow[t]{3}{*}{ Jumlah_Arah } & $\begin{array}{l}\text { Pearson } \\
\text { Correlation }\end{array}$ & ,419 &,- 116 & ,128 & ,126 & ,188 &, $589^{* *}$ & 1 &,- 028 \\
\hline & Sig. (2-tailed) &, 170 &, 591 &, 552 &, 557 & ,379 &, 002 & & ,895 \\
\hline & $\mathrm{N}$ & 20 & 24 & 24 & 24 & 24 & 24 & 24 & 24 \\
\hline \multirow[t]{3}{*}{ Ln_Arus } & $\begin{array}{l}\text { Pearson } \\
\text { Correlation }\end{array}$ &, 653 &,- 263 & ,331 &,- 116 &, $538^{* *}$ &, $417^{*}$ &,- 028 & 1 \\
\hline & Sig. (2-tailed) & ,127 & ,215 &, 115 &, 589 &, 007 &, 043 & ,895 & \\
\hline & $\mathrm{N}$ & 20 & 24 & 24 & 24 & 24 & 24 & 24 & 24 \\
\hline
\end{tabular}

Tahap awal merumuskan prediksi kecelakaan melibatkan sepeda motor adalah dengan menganalisis kesesuaian distribusi. Hasil kesesuaian distribusi menggunakan metode uji 
Kolmogorof Smirnov diperoleh data berdistribusi Poisson dan Negative Binomial. Uji outlier data dilakukan pada tahap selanjutnya untuk meninjau adakah data yang memiliki karakteristik unik yang dapat membuat bias. Hasil analisis standarisasi terhadap 24 data (24 lokasi tinjauan penelitian), terdapat 4 variabel respon sebagai data outlier, yaitu data pada lokasi penelitian 2, 8, 22 dan 24. Sehingga untuk uji multikolinieritas, empat variabel tersebut sudah tidak diikutsertakan. Uji korelasi dilakukan untuk meninjau hubungan antar variabel. Hasil uji diperlihatkan seperti Tabel 2.

Berdasarkan tabel di atas memperlihatkan variabel yang memiliki korelasi kuat terhadap variabel respon (McA) dengan variabel penjelas adalah variabel arus (Q) dan variabel kecepatan (S). Korelasi kuat variabel respon (McA) dengan variabel penjelas arus diperlihatkan dengan nilai koefisien sebesar 0,653, sedangkan dengan variabel kecepatan diperlihatkan oleh nilai koefisien sebesar 0,599. Sehingga dapat dikatakan dua variabel tersebut menunjukkan adanya pengaruh terhadap kecelakaan. Tinjauan selanjutnya dilakukan terhadap hubungan diantara variabel bebas lainnya. Nilai koefisien korelasi diperlihatkan lebih kecil dari 0,6. Hal ini memperlihatkan hubungan antara variabel dapat dikatakan lemah dan atau berkorelasi sedang, sehingga tidak terjadi multikolinearitas diantara variabel tersebut.

Untuk mendapatkan prediksi kecelakaan melibatkan sepeda motor selanjutnya dilakukan melalui analisis univariat dan analisis multivariat menggunakan distribusi poisson. Variabel penjelas yaitu arus dan kecepatan yang tidak memiliki multikolinearitas data diuji terhadap variabel respon kecelakaan melibatkan sepeda motor (McA). Hasil uji univariat dan multivariate diperlihatkan seperti pada Tabel 3 dan Tabel 4 berikut.

Tabel 3. Hasil uji univariat

\begin{tabular}{|c|c|c|c|c|c|c|c|}
\hline \multicolumn{8}{|c|}{ Parameter Estimates } \\
\hline \multirow{2}{*}{ Parameter } & \multirow{2}{*}{$\mathbf{B}$} & \multirow{2}{*}{$\begin{array}{l}\text { Std. } \\
\text { Error }\end{array}$} & \multicolumn{2}{|c|}{$\begin{array}{l}\text { 95\% Wald Confidence } \\
\text { Interval }\end{array}$} & \multicolumn{3}{|c|}{ Hypothesis Test } \\
\hline & & & Lower & Upper & Wald Chi-Square & df & Sig. \\
\hline (Intercept) & $-4,297$ & 0,890 & $-6,041$ & $-2,553$ & 23,311 & 1,000 & 0,000 \\
\hline Ln_arus & 0,941 & 0,103 & 0,738 & 1,144 & 82,866 & 1,000 & 0,000 \\
\hline (Intercept) & 2,948 & 0,115 & 2,724 & 3,173 & 661,573 & 1,000 & 0,000 \\
\hline Kecepatan & 0,026 & 0,003 & 0,019 & 0,033 & 57,704 & 1,000 & 0,000 \\
\hline
\end{tabular}

Tabel 4. Hasil uji multivariat

\begin{tabular}{|c|c|c|c|c|c|c|c|}
\hline \multicolumn{8}{|c|}{ Parameter Estimates } \\
\hline \multirow{2}{*}{ Parameter } & \multirow{2}{*}{$\mathbf{B}$} & \multirow{2}{*}{$\begin{array}{l}\text { Std. } \\
\text { Error }\end{array}$} & \multicolumn{2}{|c|}{$\begin{array}{l}\text { 95\% Wald Confidence } \\
\text { Interval }\end{array}$} & \multicolumn{3}{|c|}{ Hypothesis Test } \\
\hline & & & Lower & Upper & Wald Chi-Square & df & Sig. \\
\hline (Intercept) & $-6,097$ & 8129 & $-7,690$ & $-4,504$ & 56,254 & 1 & ,000 \\
\hline Kecepatan &, 034 & ,0034 &, 027 &, 041 & 100,645 & 1 & ,000 \\
\hline Ln_Arus & 1,030 &, 0927 & 848 & 1,211 & 123,512 & 1 &, 000 \\
\hline (Scale) & $1 \mathrm{a}$ & & & & & & \\
\hline
\end{tabular}


Dua variabel penjelas yaitu arus dan kecepatan memenuhi syarat signifikansi $<0,05$ pada hasil uji univariat. Hal ini menginformasikan bahwa arus dan kecepatan berpengaruh terhadap kecelakaan melibatkan sepeda motor. Selanjutnya dua variabel penjelas arus dan kecepatan diuji dengan variabel respon (McA) secara bersama-sama dalam uji multivariat. Hasil analisis memperlihatkan dua variabel penjelas memenuhi syarat signifikansi dengan nilai sig $<0,05$, sehingga dapat dikatakan bahwa variabel volume lalu lintas dan kecepatan lalu lintas berpengaruh signifikan terhadap kecelakaan melibatkan sepeda motor. Nilai positif ditunjukkan pada variabel arus dan kecepatan, sehingga peningkatan nilai pada arus dan kecepatan berkontribusi pada meningkatnya jumlah kecelakaan melibatkan sepeda motor pada ruas jalan.

Berdasar hasil analisis diperoleh prediksi kecelakaan melibatkan sepeda motor pada ruas jalan di Kota Surabaya seperti persamaan berikut:

$$
M c A=0,00225 Q^{1,03} e^{(0,0384 S)}
$$

Dimana $\mathrm{McA}=$ jumlah kecelakaan melibatkan sepeda motor (kejadian)

$$
\begin{aligned}
& \mathrm{Q}=\text { arus atau volume kendaraan }(\mathrm{smp} / \mathrm{jam}) \\
& \mathrm{S}=\text { kecepatan kendaraan } 85 \text { persentil }(\mathrm{km} / \mathrm{jam})
\end{aligned}
$$

Persamaan untuk prediksi kecelakaan melibatkan sepeda motor di atas dapat dipergunakan dengan karakteristik ruas jalan perkotaan dengan lebar lajur 9,0 - 28,0 m dan jumlah lajur 2 - 6 lajur serta bahu jalan dengan lebar 0 - $3 \mathrm{~m}$. Rentang kecepatan yang diijinkan antara 19,55 - $51 \mathrm{~km} / \mathrm{jam}$ dan volume kendaraan antara 1.846 - $9.675 \mathrm{smp} / \mathrm{jam}$.

\section{Komparasi Hasil Observasi Dengan Nilai Estimasi Prediksi}

Perbandingan nilai hasil prediksi dengan data observasi diperlukan untuk meninjau persamaan prediksi kecelakaan melibatkan sepeda motor. Hasil analisis diperlihatkan seperti pada gambar berikut.

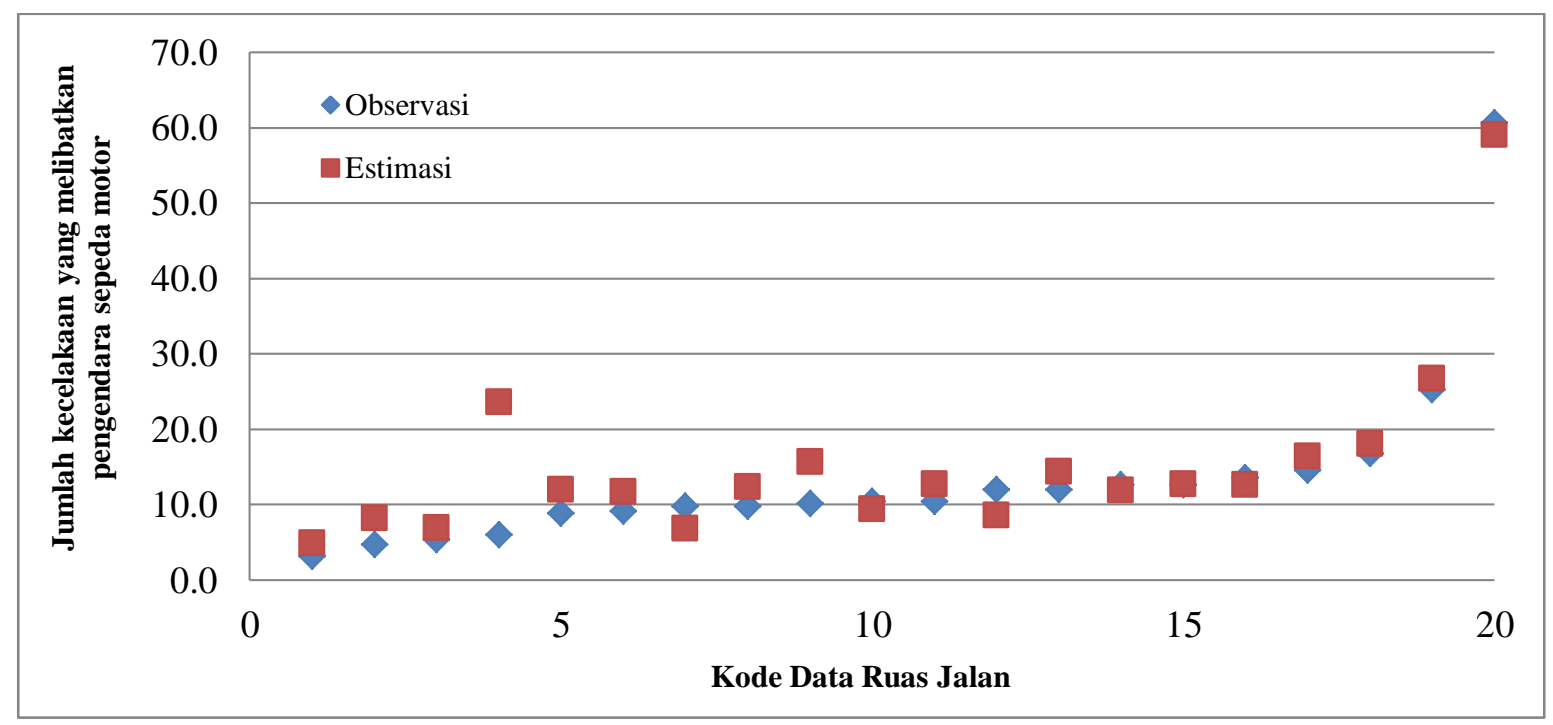

Gambar 1. Perbandingan nilai hasil prediksi dan data observasi kecelakaan melibatkan sepeda motor di Kota Surabaya 
Menggunakan uji beda rata-rata hasil estimasi prediksi kecelakaan melibatkan sepeda motor dianalisis diperbandingkan dengan hasil observasi. Data hasil observasi berupa data kecelakaan diperoleh melalui penelusuran menggunakan AIS-IRSMS. Menggunakan Uji-T dianalisis nilai signifikansi perbedaan rata-rata jumlah kecelakaan yang saling berhubungan. Berdasarkan hasil analisis diperoleh nilai signifikansi sebesar 0,53 dan lebih kecil dari 0,05. Sehingga dapat dikatakan nilai prediksi kecelakaan hasil estimasi tidak memiliki perbedaan signifikan dengan nilai kecelakaan hasil observasi.

Tabel 5. Hasil uji beda rata-rata

\begin{tabular}{|c|c|c|c|c|c|c|c|c|c|}
\hline \multicolumn{10}{|c|}{ Paired Samples Test } \\
\hline & & \multirow[t]{2}{*}{ Mean } & \multirow[t]{2}{*}{$\begin{array}{c}\text { Std. } \\
\text { Deviation }\end{array}$} & \multirow{2}{*}{$\begin{array}{l}\text { Std. } \\
\text { Error } \\
\text { Mean }\end{array}$} & \multicolumn{2}{|c|}{$\begin{array}{l}\text { 95\% Confidence } \\
\text { Interval of the } \\
\text { Difference }\end{array}$} & \multirow[t]{2}{*}{$\mathbf{t}$} & \multirow[t]{2}{*}{ df } & \multirow[t]{2}{*}{$\underset{\text { (2-tailed) }}{\text { Sig. }}$} \\
\hline & & & & & Lower & Upper & & & \\
\hline $\begin{array}{l}\text { Pair } \\
1\end{array}$ & $\begin{array}{c}\text { Nilai_observasi } \\
- \\
\text { Nilai_estimasi }\end{array}$ & - & 7,12461 & 1,59311 & $-6,61992$ & ,04892 & $-2,062$ & 19 & 053 \\
\hline
\end{tabular}

\section{KESIMPULAN}

Kecelakaan lalu lintas melibatkan sepeda motor di Kota Surabaya kurun waktu Januari 2014 hingga akhir Februari 2017 tercatat sebanyak 3.895 kejadian. Berdasarkan hasil pembahasan dapat disimpulkan antara lain:

1. Karakteristik pengendara sepeda motor terlibat kecelakaan didominasi berjenis kelamin laki-laki $(64,2 \%)$, usia pengendara berusia 15 - 25 tahun (28\%), dan profesi sebagai pegawai swasta $(68,4 \%)$.

2. Karakteristik kecelakaan menonjol melibatkan sepeda motor memperlihatkan waktu kejadian terjadi pada pukul 12.00-17.59 WIB (33,6\%), cuaca saat kejadian cerah $(90,9 \%)$, geometrik lokasi kecelakaan terjadi pada jalan lurus $(84,5 \%)$, jenis kecelakaan adalah kecelakaan ganda $(79,7 \%)$, dan jenis cedera adalah luka ringan. $(49,9 \%)$.

3. Prediksi jumlah kecelakaan melibatkan sepeda motor pada ruas-ruas jalan utama Kota Surabaya diperoleh $\mathbf{M c A}=\mathbf{0 , 0 0 2 2 5} \mathbf{Q}^{\mathbf{1 , 0 3 0}} \mathbf{e}^{(\mathbf{0 , 0 3 4}}$ S) $\operatorname{dimana} \mathrm{McA}$ adalah jumlah kecelakaan sepeda motor, $\mathrm{Q}$ adalah volume kendaraan dalam smp/jam, dan $\mathrm{S}$ kecepatan kendaraan 85 persentil dalam $\mathrm{km} / \mathrm{jam}$.

\section{UCAPAN TERIMA KASIH}

Ucapan terima kasih disampaikan kepada Direktorat Lalu Lintas Kepolisian Daerah Jawa Timur atas dukungan dan fasilitas yang diberikan dalam pengambilan data kecelakaan, serta pendampingan pemanfaatan AIS-IRSMS selama pelaksanaan penelitian. Ucapan terima kasih disampaikan pula kepada Dinas Perhubungan Kota Surabaya atas dukungan penyediaan data terkait informasi jalan dan lalu lintas pada lokasi penelitian. 


\section{DAFTAR PUSTAKA}

Abusini, S., Sulistio, H., dan Wicaksono, A.. (2010). Model Kecelakaan Sepeda Motor pada Ruas Jalan dengan Menggunakan Pendekatan GLM, Jurnal Transportasi Forum Studi Transportasi Antar Perguruan Tinggi, Vol. 10 No. 2. http://journal.unpar.ac.id/index.php/journaltransportasi/article/view/387

Ackaah, W. dan Salifu, M.. (2011). Crash Prediction Model for Two-Lane Rural Highway in the Ashanti Region of Ghana. IATSS Research. Vol.35 (2011). p.34-40.

Badan Pusat Statistik. (2017). Perkembangan Jumlah Kendaraan Bermotor Menurut Jenis, 1949-2015. https://www.bps.go.id/linkTableDinamis/view/id/1133

Badan Pusat Statistik Kota Surabaya. (2016). Kota Surabaya Dalam Angka 2015. Surabaya: Badan Pusat Statistik Kota Surabaya.

Bolla, M. E., Sir, T. M. W., dan Bara, C. N.. (2014) Pemodelan Kecelakaan Sepeda Motor Pada Ruas Jalan di Kota Atambua. Jurnal Teknik Sipil. Vol. 3 No.2. Surabaya: Jurusan Teknik Sipil, Fakultas Sains dan Teknik, Universitas Kristen Petra. http://puslit2.petra.ac.id/ejournal/index.php/jurnal-teknik-sipil/article/view/19213

Dinas Perhubungan Kota Surabaya. (2016). Laporan Akhir Analisa Kecepatan Kendaraan TahapI. Surabaya: Dinas Perhubungan Kota Surabaya.

Dinas Perhubungan Kota Surabaya. (2016). Laporan Survey Kinerja Lalu Lintas Tahun 2016 Tahap II. Surabaya: Dinas Perhubungan Kota Surabaya.

Khisty, C. J. (1990). Transportation Engineering: An Introduction. New Jersey: Prentice Hall, Englewood Cliffs.

Machsus, Sulistio, H., Wicaksono, A. dan Djakfar, L., (2013). The Prediction Models of Motorcycle Accidents on Surabaya Arterial Roads Using Generalized Linear Models. Middle-East Journal of Scientific Research. Vol. 18 No.12. p. 1859- 1866.

McCullagh, P. dan Nelder. J. A. (1989). Generalized Linear Models, 2nd edition. London, England: Chapman and Hall.

Polda Jatim. (2017). Data Kecelakaan Lalu Lintas : http://korlantas.info

Suraji, A. dan Sulistio, H.. (2010). Model Kecelakaan Sepeda Motor Pada Suatu Ruas Jalan, Jurnal Transportasi Forum Studi Transportasi Antar Perguruan Tinggi, Vol. 10 No. 1. http://journal.unpar.ac.id/index.php/journaltransportasi/article/view/377

Xie, Y., Lord, D. dan Zhang, Y.. (2007) Predicting Motor Vehicle Collisions Using Bayesian Neural Network Models: An Empirical Analysis. Accident Analysis and Prevention. Vol 39 No.5. p.922-933. 